\title{
Powieść wiecznie żywa
}

\section{The Eternal Life of the Novel}

\begin{abstract}
In this article - which is an answer to questions posed in a survey - I analyse Thomas Pavel's understanding of the history of the novel. I juxtapose his propositions with contemporary trends within literary history, emphasizing his substantial contribution to research of fictitious worlds and the literary persona. I underscore the evident intellectual affinities with the theory of Charles Taylor. Furthermore, I also examine the question of the ethics of reading from diverse standpoints (Daniel Defoe's novel serves as an example), recognizing that if there are any affinities that we can speak of at all, in this case, then they would point to theories of Martha Nussbaum rather than to the views inspired by Jacques Derrida, Richard Rorty, or feminist criticism. I focus on the selection criteria adopted by the scholar, who is less concerned with the twentieth-century novel - especially the self-referential kind - and concentrates less on various crises of values but is instead more inclined to explore novels grounded in common moral beliefs, that is those possessing "a literary safety system." Consistency of the adopted research perspective allowed the researcher to approach the genre's history in an innovative way.
\end{abstract}

Keywords: novel, history of literature, literary persona, literary genre

Streszczenie: W artykule - będącym odpowiedzią na pytania ankiety - omówiłam sposób ujęcia historii powieści zaprezentowany przez Thomasa Pavla. Zestawiłam propozycję uczonego ze współczesnymi tendencjami historycznoliterackimi, zaznaczając jego istotny wkład do badań nad fikcyjnymi światami i postacią literacką. Podkreśliłam widoczną tu wspólnotę myśli z teorią Charlesa Taylora. Z kolei kwestię etyki czytania ujęłam kilkutorowo (posługując się analizą powieści Daniela Defoe), uznając, że jeśli w ogóle można mówić o jakichś zbieżnościach, to bliżej tu do teorii na przykład Marthy Nussbaum aniżeli do optyki inspirowanej przez Jacques'a Derridę, Richarda Rorty’ego czy krytykę feministyczną. W centrum mojej uwagi znalazły się kryteria selekcji przyjęte przez uczonego, który mniejszą wagę przywiązuje do powieści XX wieku, a także do jej odmian autotematycznych, również w mniejszym stopniu koncentruje się na kryzysach wartości, chętniej bada powieści oparte na powszechnych przekonaniach moralnych, takie zatem, które dysponują „systemem bezpieczeństwa literatury”. Konsekwencja w przyjętej optyce badawczej pozwoliła uczonemu na nowe spojrzenie na historie gatunku.

Słowa kluczowe: powieść, historia literatury, postać literacka, gatunek literacki 
Nic nie wskazuje na to, żeby powieść miała umrzeć, mimo że jej zgon - jak dobrze wiadomo - wieszczono już od dawna. Jednakże po każdym ogłoszeniu zbliżającej się śmierci podnosiła się, choć zazwyczaj w nieco odmienionej postaci ${ }^{1}$. Co więcej, ostatnimi czasy wśród uczonych - wbrew prognozom sprzed kilku dekad zapowiadającym także zgon historii literatury jako nauki - wyraźnie wzrasta zainteresowanie procesem literackim ${ }^{2} \mathrm{i}$ to $\mathrm{w}$ szerokiej, kulturowej perspektywie ${ }^{3}$. Jakby tego było mało, intensywnie rozwijają się badania nad historią powieści. Świadczą o tym następujące tytuly: Margaret Doody The True Story of the Novel (1996), Michale Schmidt The Novel: A Biography (Harvard 2014), dwa tomy autorstwa Stevena Moore'a The Novel: Beginnings to 1600 i The Novel: An Alternative History 1600-1800 (London 2013). Otwierają się zarazem nowe perspektywy o charakterze czasowo-przestrzennym. Tu na pierwsze miejsce wysuwa się Franco Moretti ze słynnym dziełem Atlas of the European Novel (1998), autor znanej polskiemu czytelnikowi książki Wykresy, mapy, drzewa. Abstrakcyjne modele na potrzeby historii literatury ${ }^{4}$. Owo uprzestrzennienie ma też inny wymiar, wiąże się mianowicie z tendencjami do budowania globalnej historii literatury5.

Odpowiadając na pytania ankiety, i zarazem dziękując za miłe i zaszczytne dla mnie zaproszenie, zacznę od tego, że Thomas Pavel, uczony, który - jak o tym świadczy jego aktywność naukowa - nie podporządkowuje się w przesadnie łatwy sposób panującym modom i dominującym tendencjom, nie zamierza przedstawiać globalnej historii powieści. Koncentruje się głównie na kręgu europejskim i niekiedy amerykańskim. Dopiero w ostatniej części swojej książki otwiera bramy dla innych kontynentów ${ }^{6}$. Obce są mu też ujęcia historyczne o charakterze konstelacyjnym czy słownikowo-encyklopedycznym, ostatnio dosyć rozpowszechnione. Nie interesuje go rewizja kanonu arcydzieł, jego rozszczelnianie, włączanie tego, co marginalne, odkrywanie i zapełnianie białych plam. Unika zarazem lubianego ostatnio przymiotnika „nowa”, który zdążył się rozpowszechnić7.

${ }^{1}$ Na ten temat szeroko pisał H. Markiewicz w swojej książce Teorie powieści za granica. Od początków do schytku XX wieku, Warszawa 1995.

${ }^{2}$ Używam terminu „proces literacki” (zamiast tautologicznego: „proces historycznoliteracki”) za H. Markiewiczem i T. Walas.

3 W tym miejscu pozwolę sobie przywołać tom Kulturowa historia literatury, red. W. Bolecki, A. Łebkowska, Warszawa 2015.

${ }^{4}$ F. Moretti, Wykresy, mapy, drzewa. Abstrakcyjne modele na potrzeby historii literatury, tłum. T. Bilczewski, A. Kowalcze-Pawlik, Kraków 2016, pierwodruk w wersji oryginalnej 2007.

5 Ostatnimi czasy pojęcie literatury „globalnej”, czy „światowej” wyraźnie nabiera atrakcyjności. Świadczą o tym następujące książki: D. Damrosch, What is World Literature, Princeton 2003; Debating World Literature, red. Ch. Prendergast, London, New York 2004, czy artykuł: F. Ferguson, Planetary Literary History: The Place of the Text, „New Literary History” 2008, t. 39, nr 3 i in.

6 T. Pavel, The Lives of the Novel: A History, Princeton 2013.

7 Np.: A New History of French Literature, red. D. Hollier, Cambridge Mass. 1989; A New History of German Literature, red. D.E. Wellbery, J. Ryan, Cambridge Mass., London 2004; A New Literary History of America, red. G. Marcus, W. Sollors, Cambridge Mass. 2009. 
Tytuł książki wydanej w roku 2013, jako wersja anglojęzyczna monografii La pensee du roman (2003), brzmi The Lives of the Novel: A History. Liczba mnoga użyta przez Thomasa Pavla wskazuje na wyraźną chęć uniknięcia efektu fabuły jednowątkowej, linearnej, opartej na pojedynczym ciągu przyczynowo-skutkowym. Z kolei podsunięte przez autorów ankiety tłumaczenie słowa lives jako żywoty jest tu nad wyraz stosowne, odsłania bowiem opowieściowy charakter przestawianej teorii rozwoju powieści. Do opowieściowego charakteru ujęć historycznych zdążyli już nas skutecznie przekonać narratolodzy z Haydenem Whitem na czele, więc trudno tu o zaskoczenie, bardziej zatem intryguje sam pomysł na ową fabułę i wszystkie niuanse w nim zawarte. Otóż uczony zaprasza nas do snutej przez siebie historii bogatej i wielowątkowej, dla której punkt wyjścia stanowi opozycja między dwoma postawami charakteryzującymi postacie literackie. Pierwsza polega na dążeniu do utożsamienia się z ideałami, na ich obronie przed ciemnymi siłami i chaosem, druga - na tendencji odwrotnej. Oczywiście każda z tych postaw ulega zróżnicowaniom w ciągu dziejów, niemniej ramy zakładające ową opozycję mają charakter dla całej kompozycji książki zasadniczy, niczym kwadrat logiczny Greimasa stanowiący podstawę generowania fabuł.

Akcentując rolę postaw wobec ładu moralnego, uczony wpisuje się w zwrot badawczy, dający się zauważyć w literaturoznawstwie światowym w ostatnich dekadach XX wieku, a polegający na przywróceniu rangi postaci literackiej. W zwrocie tym najważniejszą rolę odegrały przemiany zachodzące w obrębie szeroko pojętej narratologii. Tu bowiem - jak wiadomo - badania przed laty koncentrowały się na schematach fabularnych i współgrały z odsuwaniem bohatera i jego roli fabułotwórczej na dalszy plan ${ }^{8}$. Jednakże w rezultacie osadzenia tego obszaru badań w szeroko pojętej przestrzeni kulturowej bohater literacki zaczął zajmować pierwsze miejsce. Koncentracja na takich kategoriach i pojęciach, jak płeć kulturowa, władza, etnos, a także nieustające nakierowanie badań na kwestie związane z tożsamością i wreszcie zwrot w stronę etyki (też polityki i ideologii) przyczyniły się do wydobycia roli podmiotu jako powiązanego tożsamościowo z wielkimi narracjami kultury. Pojęcie tożsamości narracyjnej rozpatrywane także w kategoriach etycznych (między innymi Charles Taylor, Paul Ricoeur) niewątpliwie ma tu też swoje zasługi i siłę inspiracji. Innymi słowy, przemiany w namyśle nad kategorią podmiotu wymusiły w sposób niejako oczywisty zainteresowanie postacią literacką.

Jednakże obok tych głównych nurtów - znanych i wielokrotnie już opisanych - warto wspomnieć o jeszcze jednym, związanym mianowicie z teorią możliwych światów. Otóż uczeni, którzy w latach osiemdziesiątych i dziewięćdziesiątych byli zwolennikami tej teorii - a należał do nich właśnie Thomas Pavel - zazwyczaj bronili postaci przez badawczą redukcją do agentów/ agensów.

8 Szeroko na ten temat pisał H. Markiewicz, zob. między innymi tenże, Wymiary dzieła literackiego, Kraków 1984, rozdział Postać literacka. 
Postulowali takie naukowe ujęcie fabuły, które ujmuje ją jako konstrukt zależny od motywacji postaci, a więc od światów jej życzeń, pragnień, moralnych zobowiązań itd. ${ }^{9} \mathrm{O}$ pierwszeństwo bohatera nad fabułą upominał się zwłaszcza Lubomir Doležel w książce z 1998 roku $^{10}$. Semantyka postaci i jej aktów stanowiła dla niego punkt wyjścia do analizy fikcyjnych światów. Twierdził dobitnie: „To świat z postaciami, lub jeszcze lepiej: to postacie wewnątrz światów generują opowieści”"1. Warto zatem przypomnieć, że Thomas Pavel należał do silnego grona rzeczników teorii możliwych światów, czemu dał wyraz między innymi w swej książce wydanej w 1987 roku, a zatytułowanej Fictional Worlds. Interesowały go wówczas głównie specyfika fikcji literackiej, jej granice i typologie, relacje między światem a tekstem. Z kolei we wcześniejszej książce Poetics of Plot, mimo że poświęconej konstrukcji fabuły, daje się zauważyć istotną rolę, jaką badacz przypisuje postaciom: ich wyborom i decyzjom.

Drugie w kolejności pytanie ankiety dotyczy rozszerzenia „wiedzy na temat źródeł nowoczesnej podmiotowości w rozumieniu Charlesa Taylora”. Przede wszystkim rzeczywiście można tu dosłuchać się pogłosów jego myśli, sytuację ułatwia ostatnia części książki, w której Pavel wymienia swoich najważniejszych inspiratorów. Na pierwszym miejscu umieszcza właśnie Taylora' ${ }^{12}$.

W istocie, jeśli przypomnimy za myślą filozofa (i innych narratywistów, zwłaszcza Paula Ricoeura), że życie przeżyte to życie opowiedziane, a zatem oparte na świadomości istotnych punktów orientacyjnych; że powiązanie między tożsamością a orientacją w przestrzeni moralnej dzięki wzorcom narracyjnym ma charakter zasadniczy, to przyznać trzeba, że u Pavla uwidoczniają się podobne założenia. Uczony proponuje konkretną, zmieniającą się w ciągu dziejów typologię bohaterów literackich; najważniejsze typy pośród nich to: mocne dusze, czułe serca i enigmatyczne psychiki. Ich drogi postępowania mogą być skrajnie różne, także oparte na zaprzeczaniu ideałów, jednakże za każdym razem najistotniejsze okazują się zmagania ze światem w wymiarze właśnie głównie moralnym i rządzonym przez narracyjne wzorce postępowania.

Jak pamiętamy, kanadyjski filozof w swojej optymistycznej i - dzięki ufności pokładanej w człowieku - wręcz terapeutycznej teorii, charakteryzuje negatywnie dominujące współcześnie tendencje, zaprzeczające „istnieniu pewnych dóbr, których ważność stanie się widoczna, jeśli przyjrzymy się dokładnie rozwojowi nowoczesnej tożsamości”. Według Taylora cecha najważniejsza, z reguły

9 W szczególności M.L. Ryan, dla której kategoria światów możliwych służyć miała nie tylko badaniu postaw i motywacji, ale zarazem precyzowaniu wymiarów ontologicznych postaci (typowych dla powieści postmodernistycznej); zob. M.L. Ryan, Possible Worlds in Literary Theory, „Style” 1992, nr 4.

${ }^{10}$ L. Doležel, „Heterocosmica”: Fiction and Possible Worlds, Baltimore, London 1998. Doležel, jako autor tej właśnie książki, wymieniany jest w The Lives of the Novel... jako jeden z inspiratorów Pavla.

${ }^{11}$ L. Doležel, dz. cyt., s. 33.

12 T. Pavel, dz. cyt., s. 313. 
niesłusznie odrzucana, a przynajmniej niedoceniana przez współczesnych myślicieli, mianowicie: „poszukiwanie porządku przez osobisty rezonans” to podstawa kośćca moralnego. Właśnie ów rezonans w czasach, gdy „powszechnie dostępny kosmiczny porządek sensów stał się niemożliwością" ${ }^{13}$, pełni funkcję podstawową dla „określenia źródeł moralności” ${ }^{14}$. Pavel tak oto pointuje jeden z rozdziałów, w którym szuka diagnozy dla samotności bohaterów współczesnych powieści:

Mimo to nigdy nie odrzucają świata wspólnych doświadczeń, ani też nie zostają uwięzieni w swoich własnych impresjach i refleksjach. I choć trudno w tych powieściach znaleźć stabilną jedność między jednostką i społeczeństwem, jednak mimo to podtrzymują naszą nadzieję, że nie jesteśmy samotnymi istnieniami ${ }^{15}$.

Można zatem przyjąć, że tak rozumiana afirmacja gatunku literackiego, upatrywanie w nim nadziei czy remedium na zagrażającą dezorientację i samotność podmiotu gotowego jednak owo remedium przyjąć, niewątpliwie współgra z teorią Taylora. W takim właśnie sensie rzeczywiście można tu mówić o pewnej wspólnocie myślenia.

Pora w tym momencie dojść do kwestii etyki czytania, która pojawia się jako kolejny punkt w ankiecie. Rodzi się jednak pytanie: czy w optyce przyjętej przez Pavla widać w ogóle inspirację zwrotem etycznym i czy rzeczywiście wymiar etyczny - we współczesnym rozumieniu - jest dla niego źródłem inspiracji?

Otóż uczonemu najbliżej do nurtu sygnowanego nazwiskami Wayne'a Bootha (mam na myśli zwłaszcza jego książkę The Company We Keep, 1988) i Marthy Nussbaum. Zresztą oboje autorzy wymienieni zostali przez Pavla jako jego główni inspiratorzy, Nussbaum nawet na pierwszym miejscu. Przy tym pamiętać trzeba, że analizowane powieści zostają dobrane tak, by działania ich bohaterów domagały się interpretacji w aspekcie właśnie etycznym. Uczony twierdzi, że „powieść staje się pierwszym gatunkiem poddającym refleksji genezę jednostki i ustanowienie powszechnej moralności”, konsekwentnie więc analizuje działania postaci pod kątem ram moralnych. Jednakże nie sposób przecież przy okazji nie zauważyć, że mamy tu po prostu do czynienia z tradycyjnym, istniejącym już od dawna, a wyraźnym zwłaszcza w wieku XIX, rozumieniem roli postaci w literaturze i samej lektury: takiego mianowicie czytania, jakiego domagał się jeszcze Georg Wilhelm

${ }^{13}$ Ch. Taylor, Źródta podmiotowości. Narodziny tożsamości nowoczesnej, tłum. M. Gruszczyński, O. Latek, A. Lipszyc, A. Michalak, A. Rostkowska M. Rychter, Warszawa 2001, s. 941.

${ }_{14}$ Tamże.

15 T. Pavel, dz. cyt., s. 296 („Yet they never reject the world of common experience, nor do they become trapped in a prison of their own impressions and reflections. It is hard to find a stable reconciliation between the individual and society in these novels; they nevertheless sustain the hope that we are not solitary beings"). 
Friedrich Hegel ${ }^{16}$. Przecież właśnie autor Wykładów z estetyki przekonywał, że „idealny charakter powinien objawiać się w zaspokajaniu nie tylko potrzeb fizycznych, lecz także potrzeb i dążeń duchowych". Owe stosunki duchowe zakładają określony związek z zastanym światem, jego normami, instytucjami, prawami moralnymi itd. ${ }^{17}$ Hegla oczywiście interesował idealny charakter, Pavlowi obca jest perspektywa wartościująca i normatywna wobec literatury, ale sama zasada oglądu postaci przez pryzmat jej relacji względem ładu moralnego jest podobna. Najsilniejsze jednak źródło inspiracji stanowi tu teoria Györgya Lukácsa, powstała jako odpowiedź na dzieło Webera i opierająca się na poszukiwaniu leku na odczarowany świat. Dla Lukácsa (przywołuję jeden z najbardziej znanych cytatów):

powieść jest tedy epopeją świata opuszczonego przez bogów; (...) jej obiektywność to męskie i dojrzałe stwierdzenie, iż nigdy sens nie przeniknie do końca rzeczywistości, ale że rzeczywistość pozbawiona sensu obróciłaby się w nicość, do której nie ma dostępu istota ${ }^{18}$.

Podążający za Lukácsem Pavel takimi słowami określa rolę powieści: „mają jedną rzecz wspólną: oferują unaocznienie tego, co idealne wewnątrz świata przemijających, kruchych i niedoskonałych działań międzyludzkich" ${ }^{19}$. A zatem analizuje postawy moralne powieściowych postaci i zarazem apoteozuje powieść jako gatunek literacki.

Gdy jednak lekturę etyczną rozumieć w duchu post-Levinasowskim, Derridiańskim albo też Rorty’owskim czy w duchu krytyki feministycznej, postkolonialnej i in., wtedy znacznie trudniej mówić o podobieństwach. Zwłaszcza jeśli pamiętać, jak Richard Rorty interpretuje „estetyzm” Vladimira Nabokova, wskazując na ścisłe powiązania między etyką i estetykąa ${ }^{20}$. Natomiast jeśli ta właśnie para pojęć pojawia się u Pavla, to na zasadzie przeciwstawnej. Powtórzyć zatem trzeba: jeśli perspektywę etyczną utożsamić z czytelniczym uwraż-

${ }^{16}$ H. Markiewicz, pisząc o ówczesnej konsekracji postaci literackiej, przypomina słowa Hegla: „Charakter stanowi (...) właściwy punkt centralny idealnego dzieła sztuki” (zob. Wymiary dzieta..., dz. cyt., s. 146).

17 G.W.F. Hegel, Wyktady o estetyce, tłum. J. Grabowski, A. Landman, t. 1, Warszawa 1964, s. 422. Przypomnijmy, jak filozof opisuje bohatera powieści Jakobiego Waldemar: „nawet dla dążeń prawdziwie etycznych, nawet dla wzniosłych celów życia pięknoduch taki nie jest dostępny, lecz osnuwa się kokonem z własnej przędzy, w którym hoduje jak najbardziej subiektywne religijne i moralne płody własnego wylęgu" (tamże, s. 388).

${ }_{18}$ G. Lukács, Teoria powieści. Esej historyczno-filozoficzny o wielkich formach epiki, tłum. J. Goślicki, posł. A. Brodzka, Warszawa 1968, s. 80.

19 T. Pavel, dz. cyt., s. 299 (w oryginale: „The lives of novel have one thing common: the bid to make the ideal visible within a world of transistory, fragile, imperfect human interactions").

${ }^{20}$ R. Rorty, Przygodność, ironia i solidarność, tłum. W.J. Popowski, Warszawa 1996. Zob. zwłaszcza rozdział Golibroda z Kasbeam. Nabokov o okrucieństwie. (Nawiasem mówiąc: Nabokov w książce Pavla wymieniony jest tylko raz, jako autor Lolity). 
liwieniem na wszelkie formy opresji, wtedy stwierdzić należy, że Pavel podąża inną drogą.

I jeszcze jedno: konsekwencja w trzymaniu się wytyczonego przez siebie szlaku wiąże się z unikaniem takich obszarów, które dla historii powieści mogłyby się wydawać zupełnie nieusuwalne. Przede wszystkim w dużo mniejszym stopniu niż postawy i działania postaci zajmują badacza kwestie sposobów ich przedstawiania. Tym samym mniej istotne okazuje się pytanie, kto i jak opowiada, ważniejsze natomiast, kto dokonuje wyborów w obrębie fikcyjnego świata i jakie pobudki nim kierują. Nie oznacza to, że cały poziom opowiadania świata nie interesuje uczonego, ogranicza się on jednak do spraw raczej podstawowych. Tym samym poza obrębem dociekań znajduje się moc sensotwórcza, tkwiąca w samych sposobach budowania narracji, które kryjąc się w strategiach narracyjnych i budując napięcie między narratorem, postacią i wreszcie samym czytelnikiem, ujawniają także pewne nośniki wartości.

Ograniczę się do jednego tylko przykładu, mianowicie do twórczości Daniela Defoe - powtórzę za badaczem - wpisującej się w nurt antyidealistyczny, realizowany jeszcze wciąż przez powieść pikarejską. Według uczonego Defoe wybiera nową drogę, odmienną od wcześniejszych powieści tego typu. Mianowicie główne bohaterki (Pavel analizuje Moll Flanders i Roxanę) muszą nieustannie się zmagać $\mathrm{z}$ wymogami społecznymi, a ich narracja pierwszoosobowa - typowa dla tej odmiany gatunkowej - ma wiązać się z tym, że znając swoje postępki, oceniają siebie, godząc się (lub nie) ze swoim dotychczasowym życiem

Nasuwa się tu jednak pewna uwaga: otóż i w jednym, i w drugim wypadku daje znać o sobie, chętnie wówczas wykorzystywana, konwencja odnalezionych pamiętników. Defoe, posługując się nią, za każdym razem zaopatruje narracje pierwszoosobowe w wyjaśniające wstępy ${ }^{21}$. Nie tylko zatem uważa za konieczne przekonywanie czytelnika o autentyczności tekstów ${ }^{22}$, ale jednocześnie wyjaśnia, dlaczego dokonał zmian, czy - innymi słowy - dlaczego niejako przepisał wspomnienia na nowo. We wstępie do Doli i niedoli stawnej Moll Flanders czytamy:

Prawda, że słowa oryginału zostały zmienione, a styl owej sławnej damy (...) uległ poniekąd przeróbce (...). Pióro, które wygładzało tę opowieść i doprowadziło ją do stanu obecnego, napotykało niemałe trudności, chcąc ją przyoblec w przystojną szatę (...). Po oczyszczeniu tej opowieści z wszelkich znajdujących się w niej momentów płochych i wyuzdanych została ona jak najstaranniej wyzyskana w celach umoralniających i religijnych ${ }^{23}$.

${ }^{21}$ Trudno nie dodać, że opowiedziane też w narracji pierwszoosobowej przygody Robinsona Cruzoe nie zostały poprzedzone analogicznym wstępem.

22 Postać przypominająca Moll ponoć rzeczywiście istniała. Por. J. Kott, Wstęp [w:] D. Defoe, Dola i niedola stawnej Moll Flanders. Z jej wtasnych zapisków, tłum. T. Tatarkiewiczowa, Warszawa 1951, s. IX.

${ }^{23}$ D. Defoe, Dola i niedola..., dz. cyt., s. 2, 3. 
Przy czym chodzi mi nie tylko o troskę o moralność czytelnika, wielokrotnie deklarowaną przez narratora, ani też o główne przesłanie, wprost wyrażone:

Każde zło, o którym mowa, jest potępione, (...) tak jak każdy cnotliwy i sprawiedliwy uczynek zyskuje pochwałę (...), nie ma sytuacji tak poniżającej czy beznadziejnej, z której nie można by się wydostać dzięki niestrudzonej pracowitości, umożliwiającej najnędzniejszemu nawet stworzeniu powrót do świata i rozpoczęcie nowego życia ${ }^{24}$.

Zgodnie bowiem z ówczesną konwencją, typową dla opowieści antyidealistycznej, narrator „starannie unika zniechęcenia odbiorcy” ${ }^{25}$ i tyle. Chodzi mi o coś innego, mianowicie o specyfikę całej sytuacji narracyjnej: opowieść kobiety zostaje ułożona i niejako spreparowana przez mężczyznę, a mimo to zostaje udostępniona czytelnikowi w pierwszej osobie w rodzaju żeńskim. Cały ten - istotny przeciez - zabieg całkowicie umyka uwadze badacza, który charakteryzuje postać Moll Flanders między innymi w taki oto sposób: „czyni zło nie tylko z konieczności, lecz także na skutek skłonności i jest zaskoczona, gdy zdaje sobie sprawę z rozmiarów swego zepsucia" ${ }^{26}$. Jednak czytelnik nie może pozostać obojętny na fakt, że ma do czynienia z dwugłosem, a dokładniej z głosem narratora, niejako - w ramach fikcji - cenzurującego myśli głównej bohaterki, doświadczającego świata w jej imieniu; zarazem z głosem takiego narratora, który całą tę sytuację odsłania czytelnikowi, traktując ją jako całkowicie oczywistą.

Podobnie rzecz wygląda w przypadku Roxany:

Historia pięknej pani winna przemówić sama za siebie. Jeśli opowieść ta nie jest tak piękna, jak sama bohaterka, jeśli nie wzbudzi w czytelnikach spodziewanego zainteresowania (...), to wina będzie po stronie tego, kto pisał te dzieje (...). (...) występki Roxany po to opisane są potępiającymi słowami, by ludzi od nich odstręczyć, a nie zachęcić do naśladownictwa ${ }^{27}$.

Krótko mówiąc: mimo iż dobrze wiadomo, że w powieściach tych mamy do czynienia z konwencją, wymogami gatunku, z uwierzytelniającą grą z odbiorcą itd., po stronie badacza zaś z konsekwentnym trzymaniem się przyjętej linii wywodu, jednak trochę żal, że sprawa specyficznego dwugłosu nie zostaje ani w artykule, ani w książce poddana analizie. Zwłaszcza że Pavel obydwu powieściom przypisuje istotną rolę: wyznaczają one mianowicie kres tradycyjnej

${ }^{24}$ Tamże, s. 3.

25 T. Pavel, dz. cyt., s. 51.

${ }^{26}$ Tamże, s. 8.

${ }^{27}$ D. Defoe, Roxana czyli szczęśliwa kochanka, tłum. J. Pawłowiczowa, Warszawa 1954, s. 13,14 . 
powieści pikarejskiej. Uogólniając: jeśliby przyjąć perspektywę etycznego czytania, które polegać ma na wspomnianej już wrażliwości, to tym bardziej tego typu strategie narracyjne powinny być brane pod uwagę.

I następny problem, znacznie ważniejszy: badacz zdecydowanie mniejszą wagę przywiązuje do powieści XX wieku, rozważania na jej temat są bardzo skrótowe, zarówno w książce, jak i w artykule (w książce ta dysproporcja jest jeszcze wyraźniejsza). Sam zresztą wprost deklaruje, że nie czuje się zobowiązany do tego, by przy takiej ilości nowych kierunków przedstawić jakąś zwartą syntezę ostatnich dziesięcioleci ${ }^{28}$. Jednocześnie ukazując historię gatunku, koncentruje się na takich postaciach literackich, które są stabilnymi ontologicznie konstruktami antropomimetycznymi. Tym samym poza kręgiem jego zainteresowań sytuują się charakterystyczna dla minionego wieku dezintegracja postaci ${ }^{29}$, a także wszelkiego rodzaju rozbicia podmiotu, począwszy od zakłóceń widocznych w imieniu własnym bohatera powieści (standardowy już przykład Powiedzmy, Gantenbein Maxa Frischa), poprzez inne sposoby narracyjne też służące zatarciu tożsamości (na przykład gra zaimkami osobowymi), aż do zatarcia statusu ontologicznego postaci (na przykład nouveau roman) itd. Nie zajmuje go też rozwijający się intensywnie w XX wieku, a wręcz wówczas dominujący, nurt powieści samoświadomej.

I konsekwentnie: skoro ukazuje losy powieści, przestrzegając przyjętej przez siebie perspektywy opisu, i bada głównie relacje między postawami idealizującymi i antyidealizującymi (ze wszystkimi tu zróżnicowaniami), znamiennymi dla powiązań podmiotu ze społeczeństwem, zakłada tym samym przejrzystą hierarchę wartości. Nic zatem dziwnego, że najłatwiej mu najpierw przedstawić ewolucję bohaterów w historii powieści od duszy, poprzez serce do psychiki, następnie dosyć szybko przemknąć się nad zawiłościami wysokiego modernizmu i powieści postmodernistycznej, by w II połowie XX wieku skupiać się głównie na odmianach gatunkowych powieści popularnej: kryminałach, fabułach detektywistycznych, westernowych, szpiegowskich, science fiction $\mathrm{i}$ innych. W nikłym stopniu interesują go wszelkie kryzysy wartości, nic zatem dziwnego, że najchętniej bada powieści oparte na powszechnych przekonaniach moralnych, takie zatem, które dysponują „systemem bezpieczeństwa literatury”" Natomiast perspektywę inną, opartą na zagrożeniu, niepewności czy właśnie na braku poczucia bezpieczeństwa stwarzanego przez stabilny system wartości, dającą o sobie znać w warstwie narracyjnej lub szerzej, w wymiarze powieściowej samoświadomości, eksperymentu itd., po prostu wymija. Niejako

28 T. Pavel, dz. cyt., s. 291.

29 Dezintegrację rozumiem za Henrykiem Markiewiczem jako „łączenie postaw i działań równocześnie czy następczo ze sobą sprzecznych lub zaskakujących i niezrozumiałych na gruncie potocznej wiedzy psychologicznej, a nie umotywowanych inaczej przez narratora” (H. Markiewicz, Wymiary dzieta..., dz. cyt., s. 147).

${ }^{30}$ Tym określeniem - cytując Rolanda Barthes’a - posługuje się Michał Głowiński [w:] tenże, Porzadek, chaos, znaczenie. Szkice o powieści wspótczesnej, Warszawa 1968, s. 28. 
z premedytacją pozostawia poza polem swoich badań te powieści, których autorzy borykają się z tego typu problemami.

W pytaniu piątym pojawia się kwestia istniejących już wizji „długiego trwania powieści”. Otóż niewątpliwie spośród tych wizji na plan pierwszy wysuwa się sformułowana przed laty przez Michaiła Bachtina, a wciąż atrakcyjna teoria upowieściowienia literatury, wyjątkowo dobrze sprawdzająca się w pobachtinowskim świecie ${ }^{31}$. Wciąż niełatwo dorównać autorowi Poetyki Dostojewskiego, trudno znaleźć współcześnie propozycję o równej sile inspiracji ${ }^{32}$. Nie zmienia to jednak faktu, że kategorie opisu historii powieści zaproponowane przez Pavla są operatywne (odpowiadam tym samym na pytanie numer 6), ale - trzeba jednak dodać - zwłaszcza dla powieści z wyrazistymi fabułami i mocno zarysowanymi postaciami. Można by mnożyć przykłady, które z łatwością dałoby się tu włączyć, ze współczesnych niektóre przynajmniej spośród powieści Olgi Tokarczuk, choćby Prowadź swój ptug przez kości umartych. Główna bohaterka, określana przez krytyków mianem tricksterki, świetnie będzie się wpisywać w Pavlowskie modele. Przykładów takich można znaleźć znacznie więcej: wczesne powieści Andrzeja Stasiuka, Jerzego Pilcha, niektóre Doroty Masłowskiej i wiele innych. Jednak powtarzam: już zakłócenia ontologiczno-epistemologiczne i rozbudowany poziom autotematyczny będą stanowić utrudnienie. Problem pojawia się nie tylko w sytuacji wspomnianej już dezintegracji postaci, rozbudowanej i zwielokrotnionej warstwy autotematycznej czy przy wszelkiego rodzaju eksperymentach, lecz także w wypadku autobiografizmów, nacisku na pamięć traumy i jej niewyrażalność, przy wszelkich komplikacjach wynikających z konstruowanej postpamięci itd. Tu nie obejdzie się bez uproszczeń, choć oczywiście można by pytać, czy są to jeszcze powieści. Z kolei pozornie niewykonalne (ale właśnie pozornie, więc zarazem jest to ciekawe wyzwanie) może się wydawać zastosowanie koncepcji badacza do powieści ukazujących różne systemy wartości, a zarazem światy oparte na różnych rodzajach logiki (dwu- i wielowartościowej), jak w wypadku twórczości Jacka Dukaja.

Trudno jednak domagać się ujęcia wszechogarniającego, uczony nakreślił wszak perspektywę badawczą z założenia zakładającą pewną selekcję, sprzyjającą takiemu kadrowaniu badawczemu, które pozwala przeprowadzić główny wątek wywodu przez całą historię gatunku, a także pomagającą uchwycić specyfikę powieści przeznaczonej dla szerokiego grona odbiorców. Pavel kilkakrotnie napomyka, że właśnie takie odmiany powieści go interesują ${ }^{33}$.

${ }^{31}$ Nawiązuję tu do książki D. Lodge'a After Bachtin: Essay on Fiction and Criticism, London, New York 1990.

32 Trzeba zaznaczyć, że w krótkim omówieniu dotychczasowych teorii powieści zawartym w książce The Lives... Pavel wypowiada się w krytyczny sposób o rozprawach Bachtina, zwłaszcza o jego sposobach analizy relacji między powieścią a społeczeństwem. Nie wnika jednak w Bachtinowskie prognozy na temat dalszej roli powieści.

${ }^{33}$ Co zresztą nie przeszkadza mu analizować na przykład powieści Franza Kafki. 
Ostatnie lata pokazały dosyć dobitnie, że wiadomości na temat śmierci powieści były mocno przesadzone, zresztą również wśród badaczy tonacja funeralna zdecydowanie zanika. W diagnozach Pavla znaleźć można optymistyczne przeświadczenie, że to właśnie odmiana popularna ma szczególną szansę na przetrwanie, tym samym towarzyszy mu przekonanie, że szeroki krąg czytelników będzie wciąż spragniony lektury. Prosi się dodać: mimo filmów i seriali (o grach komputerowych tu nie wspominam). Prosi się też dodać: oby...

Na zakończenie chciałabym się podzielić pewną uwagą: otóż we wstępie do swojej książki uczony z właściwym sobie poczuciem humoru opowiada o konkretnych powodach jej powstania. Zalążkiem były zajęcia seminaryjne prowadzone dla studentów Wydziału Komparatystyki na Uniwersytecie w Princeton. Widać więc wyraźnie, że połączenie pracy dydaktycznej z twórczością naukową może dać ważne poznawczo rezultaty. I nic w tym dziwnego, wszak takie powiazanie od zawsze stanowiło istotę nauczania uniwersyteckiego. Proponowane ostatnio na naszym gruncie rozdzielanie tych działań może się okazać zgubne w skutkach.

\section{Bibliografia}

Damrosch D., What is World Literature, Princeton 2003.

Debating World Literature, red. Ch. Prendergast, London, New York 2004.

Defoe D., Dola i niedola stawnej Moll Flanders. Z jej wtasnych zapisków, tłum. T. Tatarkiewiczowa, Warszawa 1951.

Defoe D., Roxana czyli szczęśliwa kochanka, tłum. J. Pawłowiczowa, Warszawa 1954.

Doležel L., „Heterocosmica”: Fiction and Possible Worlds, Baltimore, London 1998.

Ferguson F., Planetary Literary History: The Place of the Text, „New Literary History" 2008, t. 39, nr 3.

Głowiński M., Porzadek, chaos, znaczenie. Szkice o powieści wspótczesnej, Warszawa 1968.

Hegel G.W.F., Wyktady o estetyce, tłum. J. Grabowski, A. Landman, t. 1, Warszawa 1964.

Kott J., Wstęp [w:] D. Defoe, Dola i niedola stawnej Moll Flanders. Z jej wtasnych zapisków, tłum. T. Tatarkiewiczowa, Warszawa 1951.

Kulturowa historia literatury, red. W. Bolecki, A. Łebkowska, Warszawa 2015.

Lodge D., After Bahbtin: Essay on Fiction and Criticism, London, New York 1990.

Lukács G., Teoria powieści. Esej historyczno-filozoficzny o wielkich formach epiki, tłum. J. Goślicki, posł. A. Brodzka, Warszawa 1968.

Markiewicz H., Teorie powieści za granica. Od początków do schytku XX wieku, Warszawa 1995.

Markiewicz H., Wymiary dzieta literackiego, Kraków 1984. 
Moretti F., Wykresy, mapy, drzewa. Abstrakcyjne modele na potrzeby historii literatury, tłum. T. Bilczewski, A. Kowalcze-Pawlik, Kraków 2016.

A New History of French Literature, red. D. Hollier, Cambridge Mass. 1989.

A New History of German Literature, red. D.E. Wellbery, J. Ryan, Cambridge Mass., London 2004.

A New Literary History of America, red. G. Marcus, W. Sollors, Cambridge Mass. 2009.

Pavel T., The Lives of the Novel: A History, Princeton 2013.

Rorty R., Przygodność, ironia i solidarność, tłum. W.J. Popowski, Warszawa 1996.

Ryan M.L., Possible Worlds in Literary Theory, „Style” 1992, nr 4.

Taylor Ch., Źródta podmiotowości. Narodziny tożsamości nowoczesnej, tłum. M. Gruszczyński, O. Latek, A. Lipszyc, A. Michalak, A. Rostkowska M. Rychter, Warszawa 2001. 